\title{
Analysis for Shore Power Economy in Preventing Air Pollution of Vessels are Docked at the Berth
}

\author{
$L i$ Haibo ${ }^{1, *}$ \\ ${ }^{1}$ China Waterborne Transport Research Institute, Researcher, 100088Beijing, China
}

\begin{abstract}
Shore power can be used to effectively reduce air pollutant emission of vessels at ports when the vessels are docked at the berth. However, at present, due to investment income imbalance, enthusiasm for the construction of port and vessel enterprises and to utilize shore power is low, which causes that use proportion for shore power is low. Economy for shore power is one of the most important factors to affect the construction proportion and use of shore power. In the Paper, the influence of service charge, power price and maintenance cost of shore power on shore power economy were systematically analyzed, and investment and income of shore power were analyzed and compared. Economic indexes for payback period etc. were calculated and analyzed, and relation and influence for related factors of shore power economy were deeply analyzed. Finally, related suggestions for promoting shore power use of vessels are docked at berth were proposed from the perspective of economy.
\end{abstract}

\section{Introduction}

Shore power use while vessels are docked at berth is to replace auxiliary diesel engines on vessels with onshore power supply to power up electrical equipment for vessels during the berthing period of vessels. After auxiliary diesel engines in vessels are docked at berth is turned off, air pollutant emission of vessels at port is zero to greatly improve air quality in the port area and the surrounding and lower noise pollution. Shore power use of vessels are docked at berth is the most effective control measure to prevent air pollution for vessels are docked at berth.

As of February 2018, construction quantity for shore power facility (with power supply capacity of above $200 \mathrm{kVA}$ ) of China ports was 859, and construction proportion of planned distribution scheme for shore power at port reached $36 \%$; vessel enterprises had completed reconstruction for about 358 (3000 tonnages or above) power-receiving facilities of vessels, and construction proportion of power-receiving facilities of vessels was low, about $0.23 \%$. At present, use proportion of shore power is low. One of the important factors affecting construction and use proportion for shore power is the economy of shore power.

Economy for shore power includes two aspects, investment and income, of which investment mainly includes equipment investment and later maintenance cost input; income mainly includes service charge for shore power and subsidiary awards granted by government. Economy for vessels connected to shore power includes two aspects, investment and income, of which investment mainly includes equipment investment and later maintenance cost input; income mainly includes saved expenses compared with using shore power and auxiliary engines and financial incentives from the government, of which saved expenses compared with utilizing shore power and auxiliary engines are related to service charge of shore power charged by ports and power price.

Fuel price for vessels of current international market is relatively low, but power price for port enterprises is generally the power price in the industry and commerce industry. Two-part power price for big industrial enterprises is implemented in some ports. Apart from power price based on the amount of use, it is needed to pay the basic power price according to transformer capacity or the maximum demand, which causes that current auxiliary engine electricity generation cost for vessels is lower than power supply cost for shore power at port. There are no economic incomes in case of shore power use of vessels. The willingness of vessels to use shore power is low, and service charge for shore power that can be charged at ports is also low, which causes that construction cost of ports and vessels cannot be recovered. At present, economy analysis was conducted from the perspective of shore power investment in some port in existing literature[1]-[2], proposing shore power investment and income partially[3]-[4]. However, the influence of service charge, power price and maintenance cost for shore power on the shore power economy was not systematically analyzed, investment and income for shore power were not systematically compared and analyzed, and economic indexes for payback period etc. were not calculated and analyzed. Related factor relation and influence of shore power economy were deeply analyzed in the Paper. Finally, related suggestions for promoting shore power use while vessels are docked at berth were proposed from the perspective of economy.

\footnotetext{
* Corresponding author: 594453122@qq.com
} 


\section{Investment cost of shore power}

Investment cost of shore power mainly includes reconstruction and construction expense and equipment purchase expense, and equipment purchase expense is related to various factors such as equipment capacity and manufacturers . Equipment capacity for shore power is related to factors such as berth type and berth tonnage etc.. Investment in shore power at port and power-receiving facilities of vessels are relatively large.

Construction cost of shore power at ports for domestic
Shenzhen. These reasons cause the low construction proportion of power-receiving facilities of vessels.

\section{Service charge of shore power}

\subsection{Port maintenance expense}

At present, some provinces and districts in China have published port maintenance expense standards for vessels to use shore power, port maintenance expense for shore

Table 1. Service charge of shore power for vessels

\begin{tabular}{|c|c|c|c|}
\hline Prefecture & $\begin{array}{c}\text { Service charge of shore power } \\
\text { (yuan/kWh) }\end{array}$ & $\begin{array}{l}\text { Power price } \\
\text { (yuan/kWh) }\end{array}$ & $\begin{array}{l}\text { Port maintenance expense } \\
(\text { yuan/ } \mathrm{kWh})\end{array}$ \\
\hline Lianyungang & $\begin{array}{c}0.9801 \sim 1.1401 \text { (Coastal port) } \\
0.9801 \sim 1.2601 \text { (River port) }\end{array}$ & 0.6601 & $\begin{array}{c}0.40 \pm 0.08 \text { (Coastal port }) \\
0.50+0.10 \text { (River port })\end{array}$ \\
\hline $\begin{array}{l}\text { Jiangsu } \\
\text { Province }\end{array}$ & Determined by each city & $\begin{array}{l}\text { Implement the electricity } \\
\text { price policy of big industry, } \\
\text { Reducing the basic power } \\
\text { price, The power price is } \\
0.6601\end{array}$ & Determined by each city \\
\hline $\begin{array}{l}\text { Zhejiang } \\
\text { Provinc }\end{array}$ & $\begin{array}{c}\text { The service charge of Ningbo port is } 2 \text { yuan } \\
\qquad / \mathrm{kWh}\end{array}$ & $\begin{array}{l}\text { Implement the electricity } \\
\text { price policy of big industry, } \\
\text { Reducing the basic power } \\
\text { price }\end{array}$ & $\begin{array}{l}\text { Independent pricing of Port } \\
\text { Enterprises }\end{array}$ \\
\hline Shanghai & $\begin{array}{l}\text { Linked to the prhi } 380 \text {-CST oil price in } \\
\text { Singapore, If the closing price is less than } 300 \\
\text { dollars / ton, the value is } 0.45 \text {; The maximum is } \\
0.70\end{array}$ & $\begin{array}{c}\text { Yangshan port is } 1.06 ; \\
\text { Other port areas are charged } \\
\text { in accordance with the power } \\
\text { price of this city }\end{array}$ & 0.07 \\
\hline Shenzhen & $\begin{array}{l}\text { The government announces monthly guidance } \\
\text { price on the subsidy declaration website., In the } \\
\text { first year, the government guidance for shore } \\
\text { power tariff is not higher than } 30 \% \text { of expense for } \\
\text { vessel power generation. }\end{array}$ & $\begin{array}{l}\text { The contract price of the } \\
\text { contract between the port } \\
\text { enterprise and the power } \\
\text { supply company }\end{array}$ & $\begin{array}{l}\text { According to shore power } \\
\text { utilization rate of ocean- } \\
\text { going vessels, there are } \\
0.13,0.17,0.22 \text { and } 0.25 \\
\text { yuan } / \mathrm{kWh} \text {. }\end{array}$ \\
\hline
\end{tabular}

equipment is about 5-10 million yuan according to capacity size, and imported equipment is about 1.5-2.0 times of domestic equipment. Due to motivation for incentive policy and promotion for related policies of shore power capital of Ministry of Transport and local government, although investment in shore power facilities is relatively high, enthusiasm of port enterprises to construct shore power facilities is relatively high, and construction proportion of shore power facilities at port is gradually improved. However, operation and maintenance expenses for shore power facilities at port in the later period are relatively high, service charge for shore power by the port enterprises are lower, without income. Enthusiasm of port enterprises to apply the shore power facilities is relatively low.

For vessel enterprises, enterprise revenue is generally worse at present with relatively high reconstruction investment for power-receiving facilities of vessels. In general, about 2-3 million yuan is needed in case of domestic equipment, and imported equipment is about 1.5-2.0 times of domestic equipment. Some vessels needs to enter the shipyard for reconstruction, which may cause vessel date delay and also affect the income of ship-owner; although the state subsidizes vessels, vessel companies fail to apply for special subsidy of local government aimed at power-receiving facilities due to reasons such as fluidity operation for vessels etc.. For example, Shenzhen Municipal Government only subsidizes vessels of power at port is about 0.45 yuan- 1.3 yuan, of which four levels such as $0.13,0.17,0.22$ and 0.25 yuan $/ \mathrm{kWh}$ etc. have been set up in Shenzhen City according to utilization rate for shore power of ocean-going vessels.

\subsection{Power price by Electricity Board}

\subsubsection{Situation of foreign power price}

The power price of Electricity Board is one of the important parts to decide the service charge of shore power. The high-low of its price affects whether it is costeffective for vessels to use shore power, thus affecting the positivity of vessels to connect shore power. According to statistics, power prices in some countries of the world are shown in Table 2 .

Table 2.Power prices in parts of the world (Cent $/ \mathrm{kWh})$

\begin{tabular}{|c|c|c|c|c|}
\hline Country & Germany & France & Australia & America \\
\hline Power price & 35 & 18 & 24 & 9 \\
\hline Country & Canada & Japan & China & \\
\hline Power price & 9 & 25 & 10 & \\
\hline
\end{tabular}

The power prices in Table 2 are the average power price in various countries and the power prices in different regions of the United States are also different. The power prices are within the range of $0.046-0.25$, as shown in Fig.1. 
According to the research of EU, as the power price of EU is generally high, which is an important factor hindering the application of shore power technology in the EU. For example, Germany's power price of $\$ 0.35$ per $\mathrm{kWh}$ is nearly four times that of the average power price of the United States. Therefore, Power price by Electricity Board of the United States is relatively low, which can promote the application of the shore power technology in a certain extent.

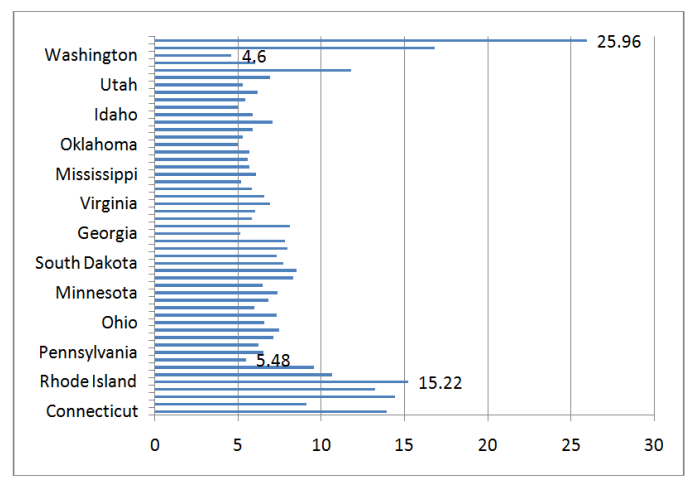

Fig. 1. Power prices in various regions of the United States $(\mathrm{Cent} / \mathrm{kWh})$

\subsubsection{Chinese power price mechanism \& price}

According to Chinese electric power mechanism reform policies, the port enterprises can acquire the electricity sale qualification and determine the power price with the electricity-sale entity or the power generation enterprise on their own, without execution of the catalogue power price at fixed expense. At present, apart from a little part of ports, most port enterprises fail to obtain the electricity qualification or obtain the electric change and power price benefit.

At present, the classification of power prices varies in provinces and cities, but mainly includes four kinds: general industrial, commercial, other power use and largescale industrial power use. As per the different calculation ways of electricity expense, the power price is also divided into the one-part power price, two-part power price and power-factor regulating power price, of which the two-part power price includes power price based on the amount of use and basic power price, and the one-part power price only comprises power price based on the amount of use. The power price based on the amount of use is categorized to power price at fixed expense and time-of-use. Two-part power price divides the power price into two parts (large-scale industrial power use $=$ power price based on the amount of use + basic power price): one is the power price based on the amount of use with electricity expense calculated at actual power consumption of the customer; the other is the basic power price to be calculated at the consumed power capacity or maximum capacity accessed to the system by the customer. Nowadays, in China, as the large-scale industrial power price policies are executed in Zhejiang Province and Jiangsu Province, with the basic electricity expense reduced, the remaining power price based on the amount of use is at relatively low expense.
At present, the power prices vary largely from one port to another in China. As shown in Fig. 2, the minimum one is about 0.66 yuan $/ \mathrm{kWh}$, while the maximum one is 1.56 yuan $/ \mathrm{kWh}$. The types and charge standards of the power price are also different, mainly centralized on the largescale industrial power price, additionally with general industrial \& commercial and industrial power use, etc.

According to the latest Chinese government policies, the basic power price are totally exempted in the shore power, so that the power price at the port in Fig. 2 may decrease to a large extent.

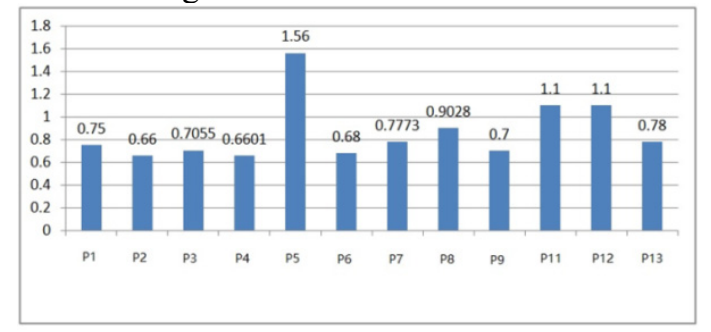

Fig. 2. Power price list of typical ports in China (yuan/kWh)

\section{Expense for vessel power generation}

Expenses for vessel power generation are the expense of the power supplied by the auxiliary engine to the vessel equipment. Whereas the price of fuel oil MGO (sulfur content: $0.1 \%$ ) used when the ocean-going vessels are docked at the berth is 515 dollars/ton, the fuel consumption rate of vessel auxiliary engine is $235 \mathrm{~g} / \mathrm{kWh}$ and the expense for vessel power generation is 0.80 yuan $/ \mathrm{kWh}$, compared with service charge of shore power of the port enterprise in the Table 1, apart from the shore power concerning the fuel charged in the Shanghai Port and Shenzhen Port is relatively low, the expenses of vessel power generation is lower than service charge of shore power in most ports. Therefore, in case of low vessel fuel price in current internal market and the expenses of vessel power generation lower than service charge of shore power, the vessel enterprises show low initiative to reconstruction and application of shore power. Meanwhile, service charge of shore power of the port enterprises cannot be too high, so that the use of shore power fails to recover the investment.

Table3.Power generation cost while vessels are docked at berth

\begin{tabular}{|c|c|c|c|c|c|}
\hline Type of vessel & \multicolumn{3}{|c|}{ Ocean-going vessels } & $\begin{array}{c}\text { Coastal } \\
\text { inland } \\
\text { trade } \\
\text { vessels }\end{array}$ & $\begin{array}{c}\text { River- } \\
\text { trade } \\
\text { vessels }\end{array}$ \\
\hline Fuel type & $\begin{array}{c}\text { MG } \\
\mathrm{O}\end{array}$ & $\begin{array}{c}\text { MD } \\
\mathrm{O}\end{array}$ & $\begin{array}{c}\text { IFO3 } \\
80\end{array}$ & $\begin{array}{c}\text { Blend } \\
\text { oil, } \\
0.5 \%\end{array}$ & $\begin{array}{c}\text { Common } \\
\text { diesel oil }\end{array}$ \\
\hline $\begin{array}{c}\text { Sulfur content } \% \\
(\mathrm{~m} / \mathrm{m})\end{array}$ & 0.1 & $<1.5$ & 3.5 & 0.5 & 0.005 \\
\hline Price (yuan/t) & 3399 & 3089 & 2145 & 3600 & 5800 \\
\hline $\begin{array}{c}\text { The cost of vessel } \\
\text { power generation } \\
\text { at } \mathrm{e}=235 \\
(\text { yuan/kWh })\end{array}$ & 0.80 & 0.73 & 0.50 & 0.85 & 1.36 \\
\hline $\begin{array}{c}\text { The cost of vessel } \\
\text { power generation } \\
\text { at e=360 } \\
\text { (yuan/kWh })\end{array}$ & 1.22 & 1.11 & 0.77 & 1.30 & 2.09 \\
\hline
\end{tabular}




\begin{tabular}{|c|c|c|c|c|c|}
\hline \multirow{2}{*}{$\begin{array}{c}\text { Type of vessel } \\
\text { Fuel type }\end{array}$} & \multicolumn{3}{|c|}{ Ocean-going vessels } & \multirow{2}{*}{$\begin{array}{c}\begin{array}{c}\text { Coastal } \\
\text { inland } \\
\text { trade } \\
\text { vessels }\end{array} \\
\begin{array}{l}\text { Blend } \\
\text { oil, } \\
0.5 \%\end{array}\end{array}$} & \multirow{2}{*}{$\begin{array}{c}\begin{array}{c}\text { River- } \\
\text { trade } \\
\text { vessels }\end{array} \\
\begin{array}{c}\text { Common } \\
\text { diesel oil }\end{array}\end{array}$} \\
\hline & $\begin{array}{c}\text { MG } \\
\mathrm{O}\end{array}$ & $\begin{array}{c}\text { MD } \\
\text { O }\end{array}$ & $\begin{array}{c}\text { IFO3 } \\
80\end{array}$ & & \\
\hline \multicolumn{6}{|c|}{$\begin{array}{l}\text { Note: 1) The current price is converted from the price of Singapore's } \\
\text { przewalskii marine fuel in September } 2017,1 \text { US dollars to } 6.6 \text { yuan } \\
\text { 2) The formula for calculating the cost of vessel power generation } \\
\text { is as follows: } \\
\text { C }=\mathrm{e} \cdot \mathrm{P} / 10^{6} \\
\mathrm{Where:} \\
\mathrm{C} \text { - The cost of vessel power generation, yuan } / \mathrm{kWh} \text {; } \\
\text { e- Fuel consumption per kilowatt hour of a vessel's engine, } \\
\mathrm{g} / \mathrm{kWh} \text {; }\end{array}$} \\
\hline
\end{tabular}

In addition, on condition that $0.5 \%$ low-sulfur oil shall be used in the vessel emission control areas as required in China, while the domestic low-sulfur oils for vessel supplied in our market are the blend oil about 3600 yuan/ton which is only 50-100 yuan/ton higher than the common domestic vessel fuel oils, at this price, the expenses for vessel power generation is 0.85 yuan $/ \mathrm{kWh}$, without advantage than service charge of shore power of port enterprises, so that the ship-owners are apt to use the low-sulfur oil, instead of switching to the port shore power.

In contrast, the use of shore power for inland river vessels has a better economic benefit. For one thing, the shore power and inland river vessels is normal frequency, not dispensing with variable frequency, so that the shore power facilities needs less investment. For another thing, according to Article 63 "The inland and river-sea transport vessels shall use the common diesel fuel up to the standard. The ocean-going vessels after reaching the port shall use the fuels for vessel meeting the air pollutant control requirements." in the Law of Prevention and Control of Air Pollution, and pursuant to the GB 252-2015 power shore in the inland rivers than in the costal and ocean areas.

\section{Comparison of service charge of shore power with expense for vessel power generation}

A comparison of expense for vessel power generation with service charge of shore power under different vessel fuel prices is shown in Fig.3.

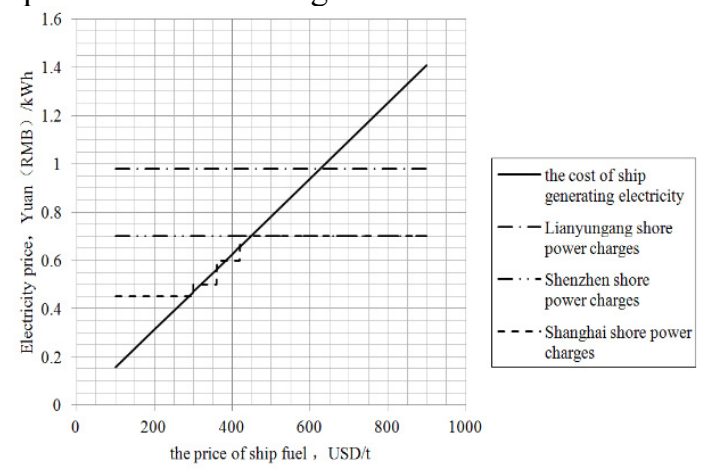

Fig.3.Comparison of service charge of shore power with expense for vessel power generation under different fuel price

It can be known from analysis in Fig.3 that the expense for vessel power generation is lower than service charge of shore power according to present oil price; that is to say that the use of shore power by vessel not only fails to generate economic benefit, but also requires paying out. In addition, there are complicated procedures, such as, separate reimbursement application of service charge of shore power, etc. Therefore, in recent years, shipping market has been depressed and enthusiasm of vessel enterprise for shore power use has been low.

Table 4.Investment payoff period of shore power

\begin{tabular}{|c|c|c|c|c|c|c|c|}
\hline & & \multirow{2}{*}{$\begin{array}{l}\text { Annual power } \\
\text { supply time } \\
\text { (h) }\end{array}$} & \multirow{2}{*}{$\begin{array}{c}\text { Electric } \\
\text { load } \\
(\mathrm{kW})\end{array}$} & \multicolumn{2}{|c|}{ Investment cost } & \multirow{2}{*}{$\begin{array}{c}\text { Income } \\
\begin{array}{c}\text { Service charge of } \\
\text { shore power } \\
(\text { yuan } / \mathrm{kWh})\end{array}\end{array}$} & \multirow{2}{*}{$\begin{array}{l}\text { Investment } \\
\text { payoff period } \\
\text { (year) }\end{array}$} \\
\hline \multicolumn{2}{|c|}{ Berth type } & & & Investment in & Port maintenance & & \\
\hline \multirow{2}{*}{$\begin{array}{l}\text { Container } \\
\text { berth }\end{array}$} & Coastal & 3600 & 2000 & 1000 & 15 & 1.2 & 4.6 \\
\hline & Inland river & 3000 & 800 & 500 & 3 & 1.3 & 5.6 \\
\hline \multirow{2}{*}{$\begin{array}{c}\text { Rolling } \\
\text { berth }\end{array}$} & Coastal & 3600 & 1000 & 700 & 10 & 1.2 & 6.6 \\
\hline & Inland river & 3000 & 700 & 400 & 3 & 1.3 & 5.1 \\
\hline $\begin{array}{c}\text { Cruise } \\
\text { berth }\end{array}$ & Coastal & 3600 & 5000 & 3000 & 40 & 1.2 & 5.5 \\
\hline
\end{tabular}

General Diesel Fuel, the diesel fuel with sulfur content not more than 50ppm, namely, the national IV common diesel fuel about 5800 yuan/ton, shall be used from July 1, 2017. At the fuel price of 5800 yuan.ton, the expense for vessel power generation is 1.36 yuan $/ \mathrm{kWh}$. On account of different fuel consumption rate, as per the actual investigation, the expense for inland river vessel power generation is about 2-3 yuan $/ \mathrm{kWh}$, so that expense for inland river vessel power generation costs a lot and the vessel enterprise can gain from the use of shore power. Therefore, it is of higher advantage to promote the use of
Therefore, for port enterprise and vessel enterprise, economic benefit of shore power is very low, so there is a lack of enthusiasm for construction and use.

\section{Investment payoff period analysis of shore power}

Benefit of shore power is mainly embodied in social benefit and environment benefit. Because purchase expense of shore power equipment is high, economic benefit is relatively poor. According to foresaid analysis 
on shore power investment cost, service charge of shore power and expense for vessel power generation, this Paper analyzes economic indexes, such as investment payoff period, etc.

Income of port enterprise mainly comes from rest part of service charge of shore power after deducting power price and investment payoff period of port shore power construction is shown as Table 4. Investment payoff period of shore power is related to annual power supply time, electrical load, investment expense and service charge of shore power, etc. Investment payoff period of port shore power is 4.6-5.6 years.

See Table 5 for investment payoff period of typical vessel. According to data in table that investment payoff period of typical vessel is related to annual shore power use time and difference of service charge of shore power
3) Under condition of fixed investment, investment payoff period of shore power is related to utilization rate and port maintenance expense charged; that is to say that the higher the use rate is, the higher the port maintenance expense charged is and the shorter the investment payoff period is. Generally, investment payoff period of shore power is 4.6-5.6 years and investment payoff period of vessel power-receiving facilities is nearly $3.9-5.8$ years. Foresaid investment payoff period does not consider fund subsidy of government departments to shore power and investment payoff period will be shortened to nearly 2 years if subsidy is considered.

4) Benefit of shore power use while vessels are docked at berth is mainly embodied in social benefit and environment benefit, and economic benefit is only a factor that port and vessel enterprises consider from their own

Table 5.Investment payoff period of typical vessel

\begin{tabular}{|c|c|c|c|c|c|c|c|}
\hline \multirow{2}{*}{\multicolumn{2}{|c|}{ Type of vessel }} & \multirow{3}{*}{$\begin{array}{c}\begin{array}{c}\text { Annual } \\
\text { power } \\
\text { supply time } \\
(\mathrm{h})\end{array} \\
1500\end{array}$} & \multirow{3}{*}{$\begin{array}{c}\begin{array}{c}\text { Electric } \\
\text { load } \\
(\mathrm{kW})\end{array} \\
2000\end{array}$} & \multicolumn{2}{|c|}{ Investment cost } & \multirow{3}{*}{ 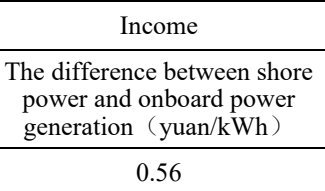 } & \multirow{3}{*}{$\begin{array}{c}\begin{array}{c}\text { Investmen } \\
\text { t payoff } \\
\text { period } \\
\text { (year) }\end{array} \\
5.8\end{array}$} \\
\hline & & & & \multirow{2}{*}{$\begin{array}{c}\begin{array}{c}\text { Investment in } \\
\text { construction ( Ten } \\
\text { thousand yuan / set) }\end{array} \\
600\end{array}$} & \multirow{2}{*}{$\begin{array}{c}\text { Maintenance expense } \\
\text { (Ten thousand yuan } \\
\text { / year) }\end{array}$} & & \\
\hline \multirow{2}{*}{$\begin{array}{c}\text { Containe } \\
\mathrm{r} \text { vessel }\end{array}$} & Coastal & & & & & & \\
\hline & $\begin{array}{l}\text { Inland } \\
\text { river }\end{array}$ & 800 & 800 & 400 & 4 & 1.7 & 4.4 \\
\hline \multirow{2}{*}{$\begin{array}{c}\text { Rolling } \\
\text { vessel }\end{array}$} & Coastal & 1500 & 1000 & 300 & 3 & 0.56 & 4.8 \\
\hline & $\begin{array}{c}\text { Inland } \\
\text { river }\end{array}$ & 800 & 600 & 200 & 3 & 1.7 & 4 \\
\hline Cruise & Coastal & 1500 & 5000 & 1000 & 15 & 0.56 & 3.9 \\
\hline
\end{tabular}

and expense for vessel power generation, etc. and investment payoff period is 3.9-5.8 years. Because use time of shore power is calculated according to statistics data, which are different in all vessel enterprises, difference of calculation results is larger.

\section{Conclusion}

1) Infrastructure investment and equipment purchase expense of port shore power and vessel power-receiving facilities are both relatively high and service charge of shore power and shore power expense paid by vessel enterprise are opposite expenses. At present, because fuel price is low, shore power expense paid by vessel enterprise is larger than expense for vessel power generation, vessel enterprise are unwilling to use shore power. Port maintenance expense is very important to restrict shore power use of port and vessel and a price recognized by both parties of the vessels and the port must be determined to facilitate shore power use by the vessels and ports.

2) At the same time, power price by Electricity Board is also an important factor to decide shore power use. In the perspective of reducing power price, it is suggested that Electricity Board in the government of China shall further reduce power price of shore power; for example, referring to residents' living power price in inland river area and adopting large industrial power price, exempt the basic power price and power capacity increasing tariff, etc. in coastal areas. benefit, and social benefit is also an important factor that enterprise shall consider. Therefore, port and vessel enterprises shall not only consider economic benefit, but also consider environment benefit and social benefit that are favourable to the country and the people when promoting development of shore power in the future.

\section{References}

1. Yu Xiao 2013.Environmental and economic benefits of vessels using shore-power. SHANGHAI: Fudan University.pp 26-34.

2. TongDaguo2013.Technology and economy research on shore-side electricity system of Tianjin port.Tianjing university. pp 30-38

3. PengChuansheng2012. Experience analysis of using shore power technology to rely on vessels in foreign countries. Port Economy.pp 12-14.

4. PengChuansheng2012. Promotion and application of shore power technology for port vessels[J].PORT OPERATION.pp1-4.

5. Los Angeles Department of Water \&Power. 2018-718 .https://www.ladwp.com/ladwp/faces/wcnav_ext ernalId/a-fr-elecrate-schel? adf.ctrlstate $=141$ e2pj32q 4\&_afrLoop $=262320023186376$ \&_afrWindowMode $=0$ \&_afrWindowId $=1 \mathrm{c} 30 \mathrm{acvf3x}$ _ $1 \# \% 40 \% 3 \mathrm{~F} \_$afrWindowId\%3D1c30acvf3x_1\%26 afrLoop\%3D $262320023186376 \% 26$ afrWindowMo de\%3D0\%26_adf.ctrl-state\%3D1c30acvf3x_29. 